\title{
CONSTITUTIONAL AND MUNICIPAL LAW
}

\author{
DOI https://doi.org/10.30525/978-9934-26-116-9-5
}

\section{ДОКУМЕНТИ РАДИ ЄВРОПИ ЯК ОСНОВА ДЛЯ РЕФОРМУВАННЯ ПРОКУРАТУРИ В УКРАЇНІ}

\author{
Рябовол Л. Т. \\ доктор педагогічних наук, професор, \\ професор кафедри державно-правових дисииплін \\ та адміністративного права \\ Центральноукраїнського державного педагогічного \\ університету імені Володимира Винниченка \\ м. Кропивницький, Украӥна
}

Прокуратура - важливий, переважно обов'язковий, орган у механізмі кожної держави. У світовій практиці накопичено значний досвід побудови системи органів прокуратури, сформувалися різні функціональні моделі, підходи до визначення правового статусу цих органів. В умовах трансформації вітчизняної правової системи, у тому числі прокуратури як їі складника, доцільним і необхідним є вивчення і впровадження позитивного зарубіжного досвіду у цій сфері. Орієнтиром наразі є відповідні положення документів Ради Свропи (РЄ), виконання яких $\epsilon$ особливо актуальним у контексті втілення євроінтеграційних прагнень нашої держави, які знайшли своє закріплення в Конституції України. Так, у Преамбулі Основного Закону акцентовано на незворотність європейського курсу України [5].

Передусім звернемося до Конвенції про захист прав людини i основоположних свобод (СКПЛ). Крім того, що у ст. 6 цього документу закріплено право кожного на справедливий суд, згідно зі ст. 13, «Кожен, чиї права та свободи, визнані в цій Конвенції, було порушено, має право на ефективний засіб юридичного захисту в національному органі, навіть якщо таке порушення було вчинене особами, які здійснювали свої офіційні повноваження» [4]. Саме діяльність прокуратури, на думку О.С. Козачука, може розглядатися як ефективний засіб правового захисту в разі порушення таких прав [3, с. 197]. У Рекомендації 1604 (2003) Парламентської Асамблеї Ради Свропи (ПАРЄ) зазначається, що в контексті виконання зобов'язань із захисту 
прав та свобод, що їх держави взяли на себе, приєднавшись до ЄКПЛ, саме органи прокуратури відіграють суттєву роль для широкого забезпечення безпеки і свободи суспільства європейських країн шляхом охорони верховенства закону, захисту громадян від кримінальних посягань на їх права і свободи, забезпечення прав та свобод осіб, які підозрюються або обвинувачуються у вчиненні кримінальних правопорушень, а також шляхом здійснення нагляду за діяльністю органів, на які покладені функції розслідування правопорушень або переслідування правопорушників [11].

Підгрунтя для реформування органів прокуратури в Україні було закладено у Висновку № 190 (1995) ПАРЄ щодо заявки України на вступ до РС. У цьому документі зазначалося, що роль та функції Генеральної прокуратури мають бути змінені таким чином, аби цей інститут відповідав стандартам РЄ, передусім щодо здійснення загального контролю за додержанням законності [2].

Значну увагу організації діяльності прокуратури ПАРС приділяє у контексті функціонування демократичних інституцій. Так, з метою надання українській владі всебічної допомоги в розбудові відкритого й демократичного суспільства в Рекомендації 1722 (2005) запропоновано інтенсифікувати, крім іншого, і реформу прокуратури та навчання прокурорів [10]. У Резолюції 1755 (2010) акцентовано на необхідність активізації заходів з реформування прокуратури; підтверджено, що функція прокуратури України щодо загального нагляду суперечить європейським стандартам, на іiі реалізацію прокуратура наділяється повноваженнями, які значно перевищують ті, що необхідні в демократичній державі; як альтернативу до функції нагляду, рекомендовано зміцнити роль омбудсмена та запровадити систему безоплатної правової допомоги [8].

РС високо оцінює роль, яку прокуратура відіграє як у системі кримінальної юстиції / кримінального правосуддя, так і поза нею, про що свідчить наявність відповідних Рекомендацій Комітету Міністрів PЄ державам-учасникам. Так, у Рекомендації 19 (2000) «Про роль прокуратури в системі кримінального правосуддя» Комітет Міністрів Р€ виходить 3 того, що прокуратура відіграє провідну роль в системі кримінального судочинства, а також у міжнародному співробітництві в кримінальних справах, а сама система кримінального судочинства має визначальне значення для захисту норм права. Згідно з цим документом, прокурори - представники органів державної влади, які від імені суспільства та в інтересах держави гарантують застосування закону, коли його порушення веде до кримінальних санкцій, враховуючи як права фізичної особи, так і необхідну ефективність 
системи кримінального судочинства [9]. Як бачимо, визначено два орієнтири в діяльності прокурора у цій сфері - права фізичної особи та власне необхідна ефективність системи кримінального судочинства, при цьому, права фізичної особи наразі є першочерговими, пріоритетними. Рекомендація 11 (2012) Комітету Міністрів РС визначає роль прокуратури поза сферою кримінального провадження - безпосередньо представництво загальних або публічних інтересів, захист прав і основоположних свобод людини, а також утвердження правової держави. Державам-учасницям наразі рекомендовано вжити всі необхідні й відповідні заходи для забезпечення того, щоб при виконанні повноважень поза системою кримінальної юстиції, прокуратура (служба публічного обвинувачення) діяла 3 особливою увагою до захисту прав людини та основоположних свобод і в повній відповідності до принципу верховенства права, зокрема, щодо права на справедливий судовий розгляд. Я. Берназюк узагальнює відповідну позицію профільних інституцій РС - участь прокурора у судовому провадженні поза межами кримінального процесу є винятком [1].

Питанню вдосконалення статусу прокуратури значну увагу Рада Європи приділяє у контексті планування дій щодо посилення незалежності та неупередженості судової влади. У відповідному плані дій, затвердженому Комітетом міністрів РС 13.04.2016, передбачено: 1) посилення незалежності прокуратури шляхом здійснення сукупності заходів, передусім із забезпечення належних правових гарантій щодо працевлаштування і строку повноважень прокурорів; 2) гарантування, що окремі прокурори не будуть піддаватися неналежному чи неправомірному зовнішньому та внутрішньому тиску, і що у своїй діяльності прокуратура загалом буде керуватися принципом верховенства права; 3) активізація заходів щодо попередження й подолання корупції в прокуратурі та посилення громадської довіри до іï діяльності [6].

У стратегічному програмному документі - Плані дій Ради Європи для України на 2018-2021 pp. [7, с. 10, 17] визнано, що позбавлення прокуратури функції загального нагляду - важливий крок у виконанні Україною зобов'язань, узятих на себе під час вступу до Ради Свропи, проте, необхідно: продовжувати реформування цієї інституції на нових конституційних засадах, вдосконалювати та узгоджувати нормативноправову базу, переглянути організаційну структуру, оптимізувати внутрішні робочі процедури з метою підвищення ефективності діяльності, зміцнення незалежності прокурорів; розробити нову систему відбору персоналу, оцінювання показників роботи, початкової підготовки та підвищення кваліфікації; у процесі підготовки до виконання прокурорських функцій застосовувати передовий європейський досвід 26 
і стандарти, закріплені у ЄКПЛ та рішеннях ЄСПЛ. У зв'язку з позбавленням прокуратури функції загального нагляду за дотриманням прав людини, у Плані наголошено на необхідність додаткового зміцнення спроможності Омбудсмена захищати права людини.

\section{Література:}

1. Берназюк Я. Міжнародні стандарти участі прокурора у судовому провадженні поза межами кримінального процесу. Судебноюридическая газета (Блог). 11.06.2020. URL: http://surl.li/yfqb

2. Висновок № 190 (1995) Парламентської Асамблеї Ради Європи щодо заявки України на вступ до Ради Свропи: Висновок, Міжнародний документ від 26.09.1995 № 190 (1995). URL: http://surl.li/yfqo (дата звернення: 06.04.2021)

3. Козачук О. С. Роль положень міжнародних документів у діяльності прокуратури у воєнній сфері поза межами кримінального провадження. Актуальні проблеми держави $і$ права. 2014. Вип. 71. С. 192-199.

4. Конвенція про захист прав людини і основоположних свобод: Конвенція, Міжнародний документ від 04.11.1950. URL: https://zakon.rada.gov.ua/laws/show/995_004\#Text (дата звернення: 06.04.2021)

5. Конституція України : Конституція, Закон від 28.06 .1996 p. № 254к/96-BP. URL: http://surl.li/gdyl (дата звернення: 07.04.2021)

6. Рада Європи: План дій щодо посилення незалежності та неупередженості судової влади: Комітет міністрів Ради Європи, План від 13.04.2016. URL: http://surl.li/yfqd (дата звернення: 05.04.2021)

7. Рада Європи: План дій для України на 2018-2021 pp. : Комітет міністрів Ради Свропи, План від 21.02.2018. URL: http://surl.li/yfqe (дата звернення: 07.04.2021)

8. Резолюція 1755 (2010) Парламентської Асамблеї Ради Європи «Функціонування демократичних інституцій в Україні» : Резолюція, Міжнародний документ від 04.10.2010 № 1755 (2010). URL: http://surl.li/yfqf (дата звернення: 06.04.2021)

9. Рекомендація 19 (2000) Комітету Міністрів Ради Свропи державам-членам «Про роль прокуратури в системі кримінального правосуддя»: Рекомендація, Міжнародний документ від 06.10.2000 № 19 (2000). URL: http://surl.li/yfqh (дата звернення: 05.04.2021)

10. Рекомендація 1722 (2005) Парламентської Асамблеї Ради Європи «Про виконання обов'язків та зобов'язань Україною» : Рекомендація, Міжнародний документ від 05.10.2005 № 1722 (2005). 
URL: https://zakon.rada.gov.ua/laws/show/994_612\#Text (дата звернення: 05.04.2021)

11. Рекомендації 1604 (2003) Парламентської Асамблеї Ради Свропи «Про роль прокуратури в демократичному суспільстві, заснованому на верховенстві закону»: Рекомендація від 27.05.2003 1604 (2003). URL: http://surl.li/yfqi (дата звернення: 05.04.2021)

\title{
DOI https://doi.org/10.30525/978-9934-26-116-9-6
}

\section{ПРАВОВА ПРИРОДА РЕЗУЛЬТАТІВ ГРОМАДСЬКОГО КОНТРОЛЮ ЗА ВИБОРАМИ}

\author{
Саркісян В. М. \\ аспірант кафедри державно-правових дисциплін \\ Луганського держсавного університету внутрішніх страв \\ імені Е. О. Дідоренка \\ м. Сєвєродонеиьк, Україна
}

Важливим аспектом при розкритті правового підходу до дослідження громадського контролю за виборами $є$ визначення ступеню обов'язковості його результатів та прийняття їх як суспільством, так і владою. Зрозуміло, що за загальним правилом результати громадського контролю за виборами не мають загальнообов'язкового юридичного характеру як у випадку, коли такого роду контроль здійснюється відповідними органами державної влади згідно з чітко встановленою процедурою та правилами, які визначені чинним законодавством. Зазвичай факти порушень чинного законодавства України, які були виявленні під час здійснення громадського контролю за виборами, мають бути перевірені та підтверджені на достовірність при розгляді звернень та скарг виборчими комісіями різного рівня, правоохоронними органами або ж взагалі у судовому порядку. Такий підхід $\epsilon$ повністю виправданим та обгрунтованим, оскільки громадський контроль за виборами цілком ймовірно може бути використаний з маніпулятивною або іншою деструктивною метою для того щоб підірвати довіру суспільства до результатів виборів, якщо вони не влаштують певного кандидата чи політичну партію, які приймали участь у цих виборах. 